UDK[272:271.2] (4-191.2)“12/14”(091)

$2-67(4-191.2) “ 12 / 14 ”(091)$

322(497)“12/14”(091)

Pregledni rad

Primljeno: 15. lipnja 2020.

Prihvaćeno za objavljivanje: 21. prosinca 2020.

\title{
ZNAČAJ PREVJERAVANJA \\ GLAVNINE ZAHUMSKO-DUKLJANSKOG ŽIVLJA \\ IZ KATOLICIZMA U PRAVOSLAVLJE \\ (13. - 14. stoljeće) ${ }^{*}$
}

\author{
Saša MRDULJAŠ \\ Institut društvenih znanosti Ivo Pilar - Područni centar Split \\ Poljana kraljice Jelene 1/1, 21000 Split \\ Sasa.Mrduljas@pilar.hr
}

U oblikovanju etničkih razlika između Hrvata, Bošnjaka, Srba i Crnogoraca presudnu je ulogu, uz posebnosti vezane uz političko-povijesni razvoj, imala religija. Na ovdašnjim prostorima prva važna vjerska distinkcija proizišla je iz njihove razdiobe između katolicizma i pravoslavlja. Međutim, inicijalna linija razdvajanja, okvirno ona iz vremena crkvenog raskola 1054. nije se dugo održala. Do njezina pomjeranja na štetu katolicizma dolazi nakon što su nekadašnje primorske kneževine Zahumlje, Travunija i Duklja, locirane između Neretve i Bojane, krajem 12. stoljeća došle pod vlast pravoslavne Srbije. S ciljem vjerske unifikacije države, a time $i$ stabilnosti vladalačkih pozicija, pod srpskom se dinastijom Nemanjića odvio proces masovnog prevjeravanja katoličkog zahumsko-dukljanskog življa u pravoslavlje. Ono je vjerojatno bilo najintenzivnije u razdoblju između osnivanja autokefalne srpske crkve, tj. Žičke / Pećke arhiepiskopije 1219. i kraja 13. stoljeća. Na taj način zahumsko-dukljanski prostor je do polovice 14. vijeka i okončanja srpske vlasti glavninom postao pravoslavnim. U priloženom radu, pored opisa političko-vjerskih prilika koje su prethodile pravoslavizaciji i utjecale na njezino provođenje, pokušat ćemo istaknuti dalekosežnost njezina značaja za ovdašnje etničke suodnose.

KLJUČNE RIJEČI: Zahumlje, Travunija, Duklja, katolicizam, pravoslavlje, prevjeravanje.

\section{Uvod}

Procesi koji su doveli do oblikovanja suvremenih nacionalnih identiteta Hrvata, Srba, Bošnjaka i Crnogoraca bili su dugotrajni, složeni, akumulirali su iskustva i htijenja po

\footnotetext{
* Ovaj je članak izrađen u okviru znanstveno-istraživačkog projekta »Povijesno oblikovanje etničkih identiteta na tlu južne Dalmacije, istočne Hercegovine i Crne Gore«, Znanstveno-istraživački projekti Instituta društvenih znanosti Ivo Pilar (2019./2020.).
} 
kojima se ti narodi međusobno razlikuju. Te realitete ne može umanjiti činjenica da su sve četiri nacije nastale iz povijesne diferencijacije nekoć kulturno istovrsne narodne mase. Njezino segmentiranje ponajprije je proizišlo iz političkih prilika. Od kada se može pratiti ovdašnji su se prostori različito razvijali politički, državno i u kontekstu inozemnih utjecaja. Stoga je na (zapadnom) južnoslavenskom tlu postojao niz samoniklih državnih tvorbi kao i krajeva koji su bili pod vlašću država izvan njegova okvira. Takva šarolikost bila je poticajna i za oblikovanje niza različitih etničkih identiteta. Oni su se relativno lako mogli izmijeniti dok god su se promjene političko-teritorijalnih odnosa odvijale na istoj jezičnoj i vjerskoj podlozi.

Različitošću političkog razvitka postupno je etablirana prva stabilna i oštra kulturna razlika očitovana kroz pripadnost katolicizmu te pravoslavlju. Pritom je linija razdvajanja u vrijeme crkvenog raskola iz 1054. godine približno išla rijekama Drinom i Tarom. Na tlu današnje Hrvatske, BiH, Crne Gore, dakle u katoličkoj sferi, Hrvatska je i nadalje bila tek jednom od više samoniklih državnih tvorevina. Istodobno u pravoslavnoj sferi srpska je država zauzimala samo jugozapadne dijelove današnje Srbije. U takvoj konstelaciji bilo je moguće da se u svakoj od navedenih dviju, jezično i dalje istovrsnih ali vjerski različitih cjelina, ovisno o političkim prilikama, odviju i procesi etničkog ujednačavanja, što se na koncu u određenoj mjeri i zbilo. No do etničkog unificiranja katolika i pravoslavca »hrvatsko-srpskog« jezika, odnosno njihovih segmenata u osnovi više nije moglo doći. U tom smislu više nije bilo dovoljno promijeniti političko-teritorijalne odnose kako bi iščezli dotadašnji identiteti. Pred integrativnim procesima sada je stajala i snažna vjerska barijera.

Katolicizam i pravoslavlje su unatoč znatnoj teološkoj ujednačenosti nastali iz svojevrsnog nadmetanja za primat unutar iste kršćanske civilizacije. ${ }^{1}$ Ono je vremenom stjecalo značajke blokovske polariziranosti pridonoseći uočljivoj identitetskoj distinkciji između katolika i pravoslavaca. Nedovoljnoj da bi spriječila suživot tamo gdje je postojala potreba za njim. Svejedno, dovoljno izražajnoj da onemogući etničku unifikaciju tamo gdje su se i katolici i pravoslavci, unatoč jezičnim i kulturnim poveznicama mogli konstituirati unutar sebi prihvatljivijeg, ujedno homogenijega državnog okvira.

Slučaj dviju europskih nacija, odnosno Albanaca i Ukrajinaca, prividno bi mogao proturječiti rečenoj tvrdnji s obzirom na to da obje uključuju katoličke i pravoslavne segmente. No kod Albanaca je prevladavajuća islamska narodna komponenta omogućila povezivanje malobrojnih albanskih katolika i pravoslavaca u okvire albanske nacije. ${ }^{2}$ Da nije bilo albanskih muslimana, da je opstala nekadašnja katoličko-pravoslavna linija razgraničenja unutar današnje Albanije, teško da bi ona bila nadiđena u korist oblikovanja transkonfesionalne albanske nacije. Ukrajinski je slučaj krajnje specifičan. Izvorno je riječ o pravoslavnoj zemlji koja pod poljskom upravom ulazi u crkvenu uniju s Rimom. Naknadno su djelovanjem Rusije poništeni njezini rezultati svugdje, izuzev u najzapadnijim dijelovima Ukrajine koji su se našli pod habsburškom vlašću. ${ }^{3}$ Drugim riječima, ukrajinski grkokato-

Juraj KOLARIĆ, Pravoslavni, Zagreb, 1985., str. 22-33, 56, 144.

Narodi Europe, Felipe FERNÁNDEZ-ARMESTO (prir.), Zagreb, 1997., str. 212-218.

3 Hugh SETON-WATSON, Nacije i države: Ispitivanje porijekla nacija i politike nacionalizma, Zagreb, 1977. str. 184-189. 
lici rezultat su povijesnog razvoja kroz koji je prolazilo cjelokupno ukrajinsko društvo te su kao takvi ostali njegovim dijelom.

Krajem 12. stoljeća pravoslavna Srbija ulazi u razdoblje ekspanzije te pored ostalog uspijeva podvlastiti katoličke zemlje južno od Tare, odnosno Zahumlje, Travuniju i Duklju (dalje: zahumsko-dukljanski prostor), i to u vremenu od kojeg se katoličko-pravoslavne proturječnosti otpočinju sve snažnije manifestirati. Sukladno takvom razvoju, u osnovi se moglo smatrati izvjesnim da će u pogodnim prilikama zahumsko-dukljanski katolici postati uzrokom političke destabilizacije Srbije. Kako bi se takvo što izbjeglo, kako bi se posredstvom »vjerskog jedinstva koje je u ona vremena bilo jedini djelujući amalgam«, državi osigurala viša razina kohezije, pokrenut je proces njegova masovnog prevjeravanja. ${ }^{4}$ Krajnji rezultat bio je taj da je glavnina zahumsko-dukljanskog življa, vjerojatno već do kraja 13. stoljeća postala pravoslavnom.

Riječ je bila o procesu koji se odvio davno, na donekle perifernom južnoslavenskom prostoru, procesu koji je ostao u sjeni tektonskih etnoteritorijalnih i kulturno-identitetskih promjena koje su se odvile tijekom osmanske dominacije. Tada će doći do kataklizmičkih pustošenja, golemih raseoba te do masovne islamizacije. No, pravoslavizacija zahumskodukljanskog prostora ipak je imala izrazitu važnost pa i na razini prikazanih zbivanja koja se odvijaju pod Osmanlijama. U priloženom radu, pored prikaza političko-vjerskih prilika koje prethode prevjeravanjima kao i političkog okvira unutar kojeg se odvijaju, pokušat ćemo ukazati upravo na dalekosežan značaj pravoslavizacije u kontekstu ovdašnjih etničkih identiteta i njihovih međusobnih suodnosa.

\section{Formativni identiteti kontekst zahumsko-dukljanskog prostora (9 - 12. stoljeće)}

Početkom 7. stoljeća bizantski limes koji se protezao Savom i Dunavom urušen je pred avarsko-slavenskim prodorima za kojih otpočinje masovna slavenska kolonizacija jugoistočne Europe. Vlast Bizanta zadržala se samo u dijelu Trakije, na pojedinim otocima i priobalnim središtima. Tako su na istočnojadranskoj obali pod bizantskom vlašću trajno ostali Krk, Cres, Lošinj, Zadar sa susjednim otocima, Trogir, Split, Dubrovnik, Kotor, Budva, Bar i Ulcinj. U tim se sredinama još zadugo održao romanski, u konačnici slavizirani živalj. Izvjesno je da su doseljenici pristizali iz različitih sjevernoslavenskih zajednica, da su se na jugu stapali u nove te da su njihovim dijelom postajali i brojni, vremenom asimilirani, starosjedioci. U onoj mjeri u kojoj su se oslobodili avarske nadmoći Slaveni su morali uspostaviti sebi svojstvene državne organizacije. Ukoliko zanemarimo druge mogućnosti te prihvatimo da su u doseobi sudjelovali etnički već formirani Hrvati i Srbi, tad se može ustvrditi da su na zapadnom dijelu Balkana već početkom 7. stoljeća ustanovljene hrvatska i srpska teritorijalna formacija. ${ }^{5} \mathrm{O}$ hrvatskoj doseobi govori bizantski car Konstantin Porfirogenet (945. - 959.) u svom radu O upravljanju Carstvom (De administrando imperio, dalje: DAI) te Splićanin Toma Arhiđakon u Povijesti salonitanske crkve

4 Vladimir ĆOROVIĆ, Istorija Srba, Beograd, 1995., str. 148-149.

5 Lujo MARGETIĆ, Etnogeneza Hrvata i Slavena, Split, 2007., str. 61-69, 115-117; Relja NOVAKOVIĆ, Odakle su Srbi došli na balkansko poluostrvo, Beograd, 1977., str. 274-350; Walter POHL, »Osnove hrvatske etnogeneze: Avari i Slaveni«, Etnogeneza Hrvata, Neven BUDAK (ur.), Zagreb, 1995., str. 94. 
iz 1261. godine. ${ }^{6}$ Pritom su po DAI-u Hrvati zauzeli rimsku provinciju Dalmaciju (koja je po predodžbama autora toga rada »počinjala od okoline Drača, odnosno od Bara i prostirala se sve do istarskog gorja a u širinu je zahvaćala do rijeke Dunav«) ali i Panoniju te Ilirik. Isti, uvelike proturječan izvor govori i o tome da su nakon Hrvata stigli Srbi te se također nastanili na tlu nekadašnje rimske Dalmacije tj. u njezinu istočnom dijelu, uključujući i primorske oblasti između ušća Cetine i Kotora. ${ }^{7}$

S obzirom na nedostatak izvora, zapravo se ne zna kakvi su bili stvarni etnički i teritorijalni odnosi u zapadnom dijelu jugoistočne Europe u 7. i 8. stoljeću. ${ }^{8}$ Za razdoblje od početka 9. vijeka sve je više podataka koji omogućavaju oblikovanje barem okvirne slike o ovdašnjim političko-teritorijalnim prilikama. Hrvatska državna jezgra nalazila se između Raše, ušća Cetine, srednje Neretve, Jadrana i gornjeg Vrbasa. Prostor današnje sjeverozapadne Hrvatske ali i sjeverozapadne Bosne bio je u 9. stoljeću pod čvršćom franačkom vlašću. U narednom vijeku na njega se širi hrvatski, a u 11. stoljeću i ugarski utjecaj. Veći dio Istre te današnja Slavonija, iako dominantno nastanjene slavenskom populacijom, uglavnom su bile pod stranom vlašću. S druge strane, srpska državna jezgra nalazila se između gornjeg Podrinja, Kosova, Tare, gornje Kolubare i donjeg Ibra. Glavnina današnje Srbije (uključujući Kosovo, ali bez Vojvodine) nakon razdoblja samosvojnog razvitka, za kojeg je u Pomoravlju mogla postojati i zajednica Moravljana, našla se do polovice 9 . stoljeća pod bugarskom te od početka 11. vijeka pod bizantskom vlašću. ${ }^{9}$

Između hrvatske i srpske jezgre nalazila se svojevrsna međuzona, približno između Vrbasa i Drine te u priobalju između ušća Cetine i Bojane. U sjevernom dijelu te zone zasigurno su zarana postavljene konture triju posebnih oblasti, tj. Bosne, Usore i Soli, koje u razvijenom i kasnom srednjem vijeku oblikuju jedinstvenu, pod imenom Bosne prepoznatljivu cjelinu. ${ }^{10} \mathrm{U}$ priobalju su se nalazile četiri manje kneževine, odnosno neretvanska između ušća Cetine i donje Neretve zajedno sa susjednim otocima; zahumska između Neretve i Dubrovnika; travunijska od Dubrovnika do Kotora te dukljanska od Kotora do Bara, Ulcinja i Skadra. Pritom je kneževina Neretva zauzimala tek manji dio zaleđa koje je, poput imotske župe, moguće pripadalo Hrvatskoj. ${ }^{11}$ Naime, po DAI-u se Zahumlje protezalo do Neretve ali se tek »prema Primorju « graničilo s neretvanskom kneževinom. ${ }^{12}$ Ostale tri

6 Toma ARHIĐAKON, Kronika, preveo Vladimir RISMONDO, Split, 1960., str. 19.

7 Vizantijski izvori za istoriju naroda Jugoslavije, tom II, Božidar FERJANČIĆ (obradio), Beograd, 1959., str. 27-32, 38-39, 49, 58.

8 Radoslav KATIČIĆ, Litterarum studia. Književnost i naobrazba ranoga hrvatskog srednjovjekovlja, Zagreb, 1998., str. 229.

9 Relja NOVAKOVIĆ, »Još o nekim pitanjima teritorijalnog prostranstva Srbije i Hrvatske sredinom 10. stoleća«, Historijski zbornik (posebni otisak), god. 19-20, br. 1-4, Zagreb, 1966-1967., str. 268, 273, 284; Trpimir VEDRIŠ, »Balkanske sklavinije i Bugarska«, Nova zraka na europskom svjetlu. Hrvatske zemlje u ranome srednjem vijeku (o. 550. - o. 1150.), Zrinka NIKOLIĆ JAKUS (ur.), sv. I. Povijesti Hrvata, Zoran LADIĆ (gl. ur.), Zagreb, 2015., str. 585-593.

${ }_{10}$ Mladen ANČIĆ, Na rubu zapada: tri stoljeća srednjovjekovne Bosne, Zagreb, 2001., str. 91, 100; Nada KLAIĆ, Srednjovjekovna Bosna, Zagreb, 1994., str. 9, 27.

${ }^{11}$ Sima ĆIRKOVIĆ, »Srbija između Vizantijskog Carstva i Bugarske«, karta: »Srbija u prvoj polovini X veka« (prema nacrtu S. Ćirkovića), Istorija srpskog naroda, knjiga 1, Sima ĆIRKOVIĆ (ur.), Beograd, 1981., str. 161.

12 Vizantijski izvori ..., tom II, str. 34. 
formacije prema sjeveru su se najvjerojatnije prostirale do rijeke Tare, odnosno do linije koja odgovara poziciji njezina toka (vidjeti kartu br. 1). ${ }^{13}$

Ukoliko pođemo od toga da su se hrvatska i srpska doseoba odvile početkom 7. stoljeća, tada bi se naknadno evidentirani podatci koji bi sugerirali hrvatsku i srpsku prisutnost u međuzoni mogli dovoditi u vezu i s najranijim razdobljima slavenske prisutnosti. Od 9. vijeka pa nadalje izvjesno je da su se utjecaji iz hrvatske i srpske jezgre širili prostorom međuzone te da su bili dijelom dinamike tadašnjih državnih suodnosa. Sukladno tomu, svakako da ti oblici hrvatske i srpske političke dinamike zaslužuju pozornost te da se bez njihova uvažavanja ne može steći odgovarajuća slika. ${ }^{14}$ No, ipak presudnu važnost u njezinu ocrtavanju ima činjenica da slavenski živalj međuzone, prvo u Primorju a zatim i u dubljem zaleđu, iskazuje značajke političke samosvojnosti koja nužno producira etničku. ${ }^{15} \mathrm{Na}$ određen način tu je samosvojnost potvrđivala i vjerska organizacija te su tako Zahumlje, Travunija, Duklja, Bosna imali vlastita biskupska središta. ${ }^{16} \mathrm{U}$ naznačenom vremenu etnički identiteti u međuzoni bili su nestabilni, a time i lako promjenjivi pod utjecajem odgovarajućih političkih prilika. No, isto je stanje bilo i u samoj hrvatskoj te srpskoj državnoj jezgri. ${ }^{17}$

Kao što je u uvodu rečeno, dok god su se procesi oblikovanja, širenja i sužavanja državnih formacija odvijali na jezično-kulturno istovrsnoj slavenskoj podlozi bilo je moguće relativno lako stjecanje, širenje i gubljenje posebnih etničkih karakteristika i imena. Takav razvoj bio je moguć još dugo nakon pokrštavanja zapadnih južnih Slavena, koje svoje masovne razmjere stječe od početka 9. stoljeća. Pritom su bili presudni zapadni utjecaji, na sjeverozapadu franački, a na jugu oni iz primorskih, romanskih enklava. Tim utjecajima bila je izložena i srpska državna jezgra, no ne i glavnina današnje Srbije. Ona će biti zahvaćena velikim valom kristijanizacije provedenim u sklopu bugarske države u drugoj polovici 9. stoljeća. ${ }^{18}$ Vrlo brzo nakon pokrštavanja među balkanskim će Slavenima, sukladno djelovanju sv. Ćirila i Metoda i njihovih učenika, prevladati ćirilometodska kršćanska forma. Ona se pored ostalog očitovala u korištenju crkvenoslavenskog jezika u liturgiji, obrednim sličnostima, uporabi glagoljice, a poslije i ćirilice. ${ }^{19}$

Unatoč prvotnim zapadnim utjecajima, srpska državna jezgra sa svojom episkopijom u Rasu, po kojoj će naknadno biti poznata i pod imenom »Raške«, približno se od prekret-

13 Jovan KOVAČEVIĆ, »Od dolaska Slovena do kraja XII vijeka«, Istorija Crne Gore, knjiga I, (predsj. red. Milinko ĐUROVIĆ), Titograd (Podgorica), 1967., str. 313-346.

${ }^{14}$ Vinko FORETIĆ, »Smještaj Hrvata i Srba u srednjem vijeku s naročitim obzirom na Crvenu Hrvatsku«, Dubrovnik, br. 4, Dubrovnik, 1969., str. 72-90.

15 Neven BUDAK, »Prilog valorizaciji humsko-dukljanskog kulturnog područja u prvim fazama njegova razvitka (do 12. st.)«, Starohrvatska prosvjeta, br. 16, Zagreb, 1986., str. 125, 131, 138.

16 Tibor ŽIVKOVIĆ, »O počecima Bosne u ranom srednjem vijeku«, Godišnjak, knjiga 39, Sarajevo, 2010., str. 152.

17 »Pri ovome se često gubilo iz vida da u ranom srednjem veku ne može da bude govora o postojanju nekog srpskog ili hrvatskog identiteta izvan političkih okvira njihovih kneževina. Etnički moment je zapravo potpuno podređen političkom, pa je tako i formiranje plemenskih državica Južnih Slovena posledica političkog razvitka, a ne nekakvog nezavisnog razvoja etničke / plemenske svesti.« Tibor ŽIVKOVIĆ, »Neretljani - primer razmatranja identiteta u ranom srednjem veku«, Istorijski časopis, knjiga 61, Beograd, 2012., str. $12-13$.

18 Sima ĆIRKOVIĆ, »Obrazovanje srpske države«, Istorija srpskog naroda, knjiga I, str. 151-153.

${ }^{19}$ Fransis KONT, Sloveni: Nastanak i razvoj slovenskih civilizacija u Evropi (VI-XIII vek), knjiga II, Beograd, 1989., str. 446-473. 
nice 9. u 10. stoljeće nalazi pod bugarskom crkvom, odnosno od 1020. godine pod ohridskom arhiepiskopijom. ${ }^{20}$ Tako će do crkvenog raskola iz 1054. današnja Srbija južno od Save i Dunava te dio današnje Crne Gore sjeverno od rijeke Tare biti čvrsto ukorijenjeni u pravoslavnoj, a današnja Hrvatska, BiH i veći dio Crne Gore u katoličkoj sferi. ${ }^{21}$ Tu će razdiobu donekle amortizirati ćirilometodska tradicija, koja će biti prisutna i među katolicima jadransko-dinarskog pojasa pa tako i onima koji su obitavali u Zahumlju, Travuniji i Duklji. $^{22}$ U znatnoj mjeri ublažavat će je i fond jezično-folklornih istovrsnosti ili sličnosti. Svejedno, jedna od najznačajnijih manifestacija kulture, ona koja se odnosi na vjerskosvjetonazorski sustav postala je linijom razdiobe. Razumljivo da je i u tim uvjetima bila moguća državna ekspanzija iz katoličke južnoslavenske »sfere« u pravoslavnu i obratno. No, ona sama po sebi više nije mogla rezultirati etničkom unifikacijom između vjerski podvojenog življa.

U kontekstu primorske međuzone, koja nas ovdje posebno zanima, od prekretnice 10 . u 11. stoljeće prisutne su dvije razvojne tendencije. Oblast Neretljana, koja je kontinuirano bila povezana s dinamikom odnosa u Hrvatskoj, sve se intenzivnije integrira u njezinu političku i društvenu stvarnost. Ta integracija će tek naknadno postati sveobuhvatnom, rezultirajući uklapanjem u hrvatski državni okvir. ${ }^{23} \mathrm{~S}$ tim da do kraja srednjeg vijeka cjelokupan pojas između Cetine i Neretve ostaje njegovim perifernim, nestabilno uvezanim dijelom. ${ }^{24}$ Nasuprot tome, ostale primorske oblasti imale su drukčiji povijesni put.

Početkom 11. stoljeća, u sklopu svog konačnog obračuna s Bugarskom Bizant uspijeva pod svoj nadzor staviti najveći dio Balkana, uključujući Bosnu, Srbiju te zahumskodukljanski prostor. U tim uvjetima, dukljanski knez Vojislav podiže 1039. - 1040. ustanak, koji će dovesti ne samo do zbacivanja bizantske vlasti nego i do zauzimanja susjednih slavenskih država. Za razliku od Bosne i Srbije, u kojima je dukljanska vlast trajala kratko, Zahumlje i Travunija su mnogo čvršće integrirani i to unutar države koja u drugoj polovici 11. stoljeća stječe punu afirmaciju. Potvrđenu pored ostalog od strane papinstva, koje joj priznaje status kraljevine te uspostavom »krovnog« vjerskog središta u vidu barske metropolije. ${ }^{25}$ Tako je barska crkva postala političkim osloncem dinastiji Vojislavljevića i snažnim uporištem katolicizma na zahumsko-dukljanskom prostoru. Naznačeni tijek događaja mogao je sugerirati pojavu nove, znatno etabliranije državno-etničke formacije na teritoriju od nekih $20000 \mathrm{~km}^{2}$ ili veličine današnje Slovenije. No, krajem 12. stoljeća zahumsko-dukljanski prostor ulazi u razdoblje političkih, kulturnih, vjerskih promjena nakon kojih će njegova razvojna linija biti radikalno preusmjerena.

\footnotetext{
${ }^{20}$ Ivana KOMATINA, Crkva i država u srpskim zemljama od XI do XIII veka, Beograd, 2016., str. 74-77, 91.

${ }^{21}$ Eduard PERIČIĆ, Sclavorum regnum Grgura Barskog, Zagreb, 1991., str. 48-61.

${ }_{22}$ Milenko KREŠIĆ, »Vjerske prilike u Humskoj zemlji (Stonu i Râtu) u srednjem vijeku«, Hercegovina, br. 2, Mostar, 2016., str. 69-71.

${ }^{23}$ „ Sigurno je da se kneževina Neretljana u 11. stoljeću našla na putu ekspanzije i da je bila uključena u Hrvatsku Kraljevinu. Tada se za pojas između Cetine i Neretve, zbog graničnog položaja, ustalio naziv Krajina. Među stanovnicima Krajine značajnu su ulogu imali Kačići, potomci jednoga od starih hrvatskih plemena.« Sima ĆIRKOVIĆ, Srbi među europskim narodima, Zagreb, 2008., str. 33.

${ }^{24}$ Hrvatski povijesni atlas, Krešimir REGAN (ur.), Zagreb, 2003., str. 79-98.

${ }^{25}$ Katarina MITROVIĆ, »Kraljevstvo od iskona: Barska (arhi)episkopija i Duklja«, Serbian Kingdoms in the Midle Ages. Proceedings of the International Scientific Conference Held in Kraljevo, September 15-17, 2017., Siniša MIŠIĆ (ur.), Kraljevo, 2017., str. 64-65, 69-73.
} 


\section{U okvirima srpske države (13. - 14. stoljeće)}

Polovicom 12. stoljeća dolazi do slabljenja i dezintegracije dukljanske države što se očituje i u njezinoj degradaciji na rang kneževine i potpadanju pod vrhovnu vlast Bizanta. Istodobno, uz ugarske poticaje sve više snaži susjedna Srbija, posebice za velikog župana Stefana Nemanje (1166. - 1196.). Tomu će pogodovati sve izražajnije slabljenje bizantskih pozicija na Balkanu uvelike uzrokovano seldžučkim pritiscima u Maloj Aziji. U konačnici, tu će situaciju iskoristiti kršćanske države, među kojima i Srbija, kako bi zauzele dotadašnje bizantske teritorije. ${ }^{26}$ Tako će Nemanja od 1183. do 1190. proširiti svoju vlast na znatan dio Pomoravlja te na veći dio Kosova, čime će udvostručiti Srbiju na blizu $40000 \mathrm{~km}^{2}$. Također će se pod njegovom vlašću naći i zahumsko-dukljanski prostor te dijelovi današnje Albanije uz rijeku Drim. Sve se to odvijalo u prilikama koje će gotovo idućih dvjesto godina pogodovati stabilnosti države Nemanjića i njezinoj daljnjoj ekspanziji. Postajući respektabilnom državom, srpski su vladari nužno trebali osigurati i vlastitu crkvenu organizaciju, koja bi bila polugom održanja i stabilnosti njihove vlasti. Unatoč tomu što je na zahumsko-dukljanskom prostoru postojao etabliran vjerski centar u vidu barske (nad)biskupije, činjenica je da su dvije trećine države bile pravoslavne i da se perspektiva njezina širenja otvarala samo u pravoslavnoj sferi. Stoga je bio razumljiv izbor Nemanjića da svoj oslonac potraže u pravoslavlju. Tim više što su nakon križarskog zauzimanja Carigrada i uspostave Latinskog Carstva 1204. godine, Bizant i njemu podređene, u pravoslavlju vodeće crkvene strukture dovedene u poziciju da pristaju na rješenja na koja u drugim uvjetima ne bi pristajale. Tako 1219. godine zalaganjem Rastka Nemanjića (sv. Save), odnosno Nemanjina sina te uz odobrenje bizantskog cara i patrijarha nastaje autokefalna srpska crkva u vidu Žičke arhiepiskopije.

Raskol između katoličke i pravoslavne crkve iz 1054. godine je bio na liniji raskola kakvih je i prije bilo između Rima i Carigrada te koje se uspijevalo nadići u interesu crkvenog jedinstva. No, poslije uspostave Latinskog Carstva i time izazvane degradacije Bizanta dotadašnji raskol akumulira toliku razinu polariteta da stječe značajke blokovske, do danas aktualne razdijeljenosti. ${ }^{27}$ Proces prožimanja katoličko-pravoslavnih relacija sve izražajnijim distinktivnim sadržajima otpočinje upravo u vremenu za kojeg se zahumsko-dukljanski prostor nalazi pod pravoslavnim vladarima i unutar države koja raspolaže vlastitom, izuzetno dobro organiziranom pravoslavnom crkvom.

Svijest o katoličko-pravoslavnim razlikama postojala je u državi Nemanjića i neovisno o događajima koji su se odvili u kontekstu Bizanta. Sam Stefan Prvovjenčani, sin i nasljednik Stefana Nemanje, u žitiju svog oca govori o tome kako je Nemanja, kao dijete srpskog izbjeglice u Duklji kršten kod današnje Podgorice od strane »latinskih jereja« te da je po povratku u domovinu iznova bio kršten u pravoslavlju i to »usred srpske zemlje«, u crkvi sv. Petra i Pavla kod današnjeg Novog Pazara. ${ }^{28}$ Vrlo je upitno je li se drugo krštenje uopće

\footnotetext{
${ }^{26}$ Georgije OSTROGORSKI, Istorija Vizantije, Beograd, 1996., str. 367-382.

${ }^{27}$ Sima ĆIRKOVIĆ, »Zeta u državi Nemanjića«, Istorija Crne Gore, knjiga II: tom I, (predsj. red. Milinko ĐUROVIĆ), Titograd (Podgorica), 1970., str. 18-19; Stivn RANSIMEN, Vizantijska civilizacija, Beograd, 1964., str. 122; Dragoje ŽIVKOVIĆ, Istorija crnogorskog naroda, knjiga I, Cetinje, 1989., str. 147-148.

28 Stefan PRVOVENČANI, Sabrani spisi, Ljiljana JUHAS-GEORGIEVSKA (prir.), Beograd, 1989., str. 64-65.
} 
zbilo s obzirom da ono nije bilo nužno kako bi se iz katolicizma prešlo u pravoslavlje. ${ }^{29}$ No, navedeni podatak govori o jasnom uočavanju vjerskih razlika između zahumskodukljanskog prostora i Srbije te nagovještava način njihova nadilaženja.

Očito je da je tada postojao jedan dodatni fond sličnosti između katolicizma i pravoslavlja koji je unutar vjerničkih masa umanjivao doživljaj međusobnih razlika. Te sličnosti su se još snažnije očitovale na ovdašnjoj katoličko-pravoslavnoj liniji razdvajanja. Tako su se obje crkve koristile istim kalendarom, još uvijek nije bilo neobično da se žene i niži katolički svećenici, snažno je bilo zastupljeno ćirilometodsko nasljeđe. ${ }^{30}$ Međutim, postojao je i jedan fond posebnosti kojeg je obična pastva morala biti svjesna s obzirom na to da su bile dijelom vjerskih ili vjersko-tradicijskih vrijednosti, takvih koje su crkvene strukture bile dužne unositi među vjernike.

Među katolicima se jedna od najuočljivijih posebnosti odnosila na istaknuto mjesto papinstva unutar vlastite vjerske konstrukcije. Pritom je svijest o njegovu značenju praktički od pokrštenja inkorporirana među kršćane pod jurisdikcijom rimskog patrijarhata. $\mathrm{O}$ tome npr. upečatljivo govori Konstantin Porfirogenet u kontekstu Hrvata. U DAI-u stoji da su Hrvati »dobili neko proroštvo i zapovijest od rimskog pape, koji je za Heraklija cara Romeja poslao svećenike i njih pokrstio. Naime, ovi Hrvati poslije svoga pokrštavanja dadu svojeručno potpisanu obvezu, pod čvrstom i nepokolebljivom zakletvom u sv. Petra Apostola, da nikada neće provaliti u tuđu zemlju i ratovati, već da će radije živjeti u miru sa svima koji to žele, primivši od istog rimskog pape ovaj blagoslov: ako neki drugi narodi pođu protiv zemlje ovih Hrvata i zarate, neka za njih (Hrvate) ratuje Bog Hrvata i štiti ih i pobjedu im donese Petar Kristov učenik. « ${ }^{31}$ Također u DAI-u stoji i to da vjerojatno polovicom 9. stoljeća ${ }^{32}$ u Hrvatsku dođe »neki krajnje pobožan čovjek po imenu Martin, obučen u svjetovno odijelo, koji je, pričaju isti Hrvati, činio mnoga čuda ... On istim Hrvatima ponovo preporuči da do kraja svoga života čuvaju ovu zapovijest njegove svetosti pape, podijelivši im i sam blagoslov sličan papinskome. $\ll^{33}$

U osnovi istovrstan odnos prema papinstvu morao se oblikovati i na zahumsko-dukljanskom prostoru. Nadbiskup barski Ivan u svojoj poslanici upućenoj papi Inocentu III. iz 1199. godine, pored ostalog navodi: »Ja sam pak spreman svom dušom i na svaki način za cijeloga svog života biti privržen i vjeran tebi i svetoj Rimskoj crkvi.« ${ }^{34} \mathrm{Ne}$ treba sumnjati da i ta značajna osobitost katolicizma nije unošena među vjernike. Pored svijesti o papinstvu, među katolike zahumsko-dukljanskog prostora morao je biti inkorporiran i određeni kult dinastije Vojislavljevića. Oni su bili vjerni katolici, o čemu svjedoči i to da su sahranjivani u crkvama [sv. Marije (Krajina), sv. Andrije (Prapratna), sv. Juraja (stolna crkva barske metropolije)] i samostanima [sv. Sergija i Bakha (Bojana), sv. Petra od Polja

\footnotetext{
29 Lenka BLEHOVA ČELEBIĆ, Hrišćanstvo u Boki 1200-1500: kotorski distrikt, Podgorica, Cetinje, 2006., str. 362; Niko IKIĆ, »Sakramenti in genere, communicatio in sacris i sakramenti u katoličkom i pravoslavnom nauku i praksi«, Bogoslovska smotra, god. 80, br. 4, Zagreb, 2010., str. 1172.

${ }^{30}$ Marija MARIĆ - Marinka ŠIMIĆ - Ante ŠKEGRO, »Pop Tjehodrag i njegov natpis«, Povijesni prilozi, god. 26, br. 33, Zagreb, 2007., str. 28-29; Milenko KRES̆IĆ, »Vjerske prilike u Humskoj zemlji«, str. 76-77.

31 Vizantijski izvori ..., tom II, str. 42.

${ }^{32}$ Ivo GOLDSTEIN, Hrvatski rani srednji vijek, Zagreb, 1995., str. 236, 302.

33 Vizantijski izvori ..., tom II, str. 43.

${ }^{34}$ Ivan MARKOVIĆ, Dukljansko-barska metropolija, Zagreb, 1902., str. 95; Monumenta Montenegrina (Arhiepiskopija barska), knjiga IV, tom I, Vojislav D. NIKČEVIĆ (prir.), Podgorica, 2001., str. 84.
} 
(Trebinje), sv. Benedikta (otok Lokrum kod Dubrovnika)]. ${ }^{35}$ Da je katolička crkva imala afirmativan odnos prema Vojislavljevićima vidi se i iz sadržaja Ljetopisa popa Dukljani$n a$, vjerojatno napisanog od strane barskog (nad)biskupa Grgura (1172. - 1195.) između 1177. - 1189. Pa i iz toga da pred Nemanjinim prodorom prema Jadranu kneginja Desislava, supruga zadnjeg dukljanskog kneza Mihaila, zajedno s barskim nadbiskupom Grgurom i dijelom vlastele, napušta 1189. godine Bar i odlazi u Dubrovnik. ${ }^{36}$

Iako je na zahumsko-dukljanskom prostoru postojala odgovarajuća razina svijesti o pripadnosti katolicizmu teško da je ona kod vjerničkih masa brzo nadograđivana onom vrstom polariziranih sadržaja koji između katolicizma i pravoslavlja nastaju nakon 1204. godine. Takvo što se tek trebalo odviti. Premda bi taj proces išao brže da se održao autentičan razvitak, on bi se odvio i pod srpskom vlašću. Sveukupno, zahumsko-dukljanski prostor ne samo da je po svom katolicizmu i državnim tradicijama, po kojima je jasno razlikovan od »srpske zemlje« čak i u 13. vijeku, ${ }^{37}$ bio distanciran od Srbije nego je trebao steći sadržaje koji bi dodatno pogodovali destabilizaciji državne vlasti. S obzirom na takve okolnosti, pod Nemanjićima se otpočinje provoditi proces prevjeravanja zahumsko-dukljanskih katolika u pravoslavlje. Zasigurno odmah po osnivanju i ustroju Žičke arhiepiskopije, kada su osnovane i humska, zetska i budimljanska episkopija, koje su pod svojom jurisdikcijom imale zahumsko-dukljanski prostor, odnosno njegove dijelove.

Politički gledano riječ je bila o smislenom i pravodobno izvedenom potezu, u razdoblju dok je još uvijek bilo moguće izvesti takvo prevjeravanje bez znatnijih turbulencija. To će pokazati naknadni razvoj događaja. Početkom 14. stoljeća sve više jača izvanjski katolički pritisak na Srbiju, pri čemu se kao s faktorom destabilizacije računa i s njezinim preostalim katoličkim življem. Kakvo je bilo njegovo raspoloženje dobro oslikava jedna izjava iz 1319. godine u kojoj albanske vođe izjavljuju da su spremne »kao katolički muževi uhvatiti priliku i stresti jaram pravog šizmatika i neprijatelja kršćanske vjere, perfidnoga kralja raškoga $\ll^{38}$. Posebno upečatljivo o doživljaju srpske vlasti među katolicima svjedoči barski nadbiskup Guillaume Adam, koji 1332. godine sugerira francuskom kralju Filipu VI. da u osloncu na progonjene i ogorčene katolike u državi Nemanjića osvoji »kraljevstvo Raške ${ }^{39}$

O tome na koji je način i u kakvim uvjetima provođeno prevjeravanje poseban je istraživački problem. Vidno je da su Nemanjići morali taktizirati sa Zapadom i sa samim papinstvom. Ono je nerijetko uključivalo i formalne manifestacije odanosti Rimskoj crkvi, pa čak i iskazivanje spremnosti na uniju. ${ }^{40}$ I dok se time mogao stvoriti dojam da će katolicizam upravo preko srpske Crkve osigurati prodor na Balkan, u stvarnosti je upravo njezinim djelovanjem rastakan prostor između Neretve i Bojane. Tom su procesu mogla

\footnotetext{
${ }^{35}$ Ljetopis popa Dukljanina, predgovor, popratni tekstovi i prevod Slavko MIJUŠKOVIĆ, Beograd, 1988., str. $129,136,138,139,141,142,143,145$.

36 E. PERIČIĆ, Sclavorum regnum, str. 48, 175, 61-62.

37 Predrag KOMATINA, »Srbija i Duklja u delu Jovana Skilice«, Zbornik radova Vizantološkog instituta, br. 49, Beograd, 2012., str. 167-168.

${ }^{38}$ Ivan MARKOVIĆ, Dukljansko-barska metropolija, Zagreb, 1902., str. 111-112; Milan ŠUFFLAY, Srbi $i$ Arbanasi, Zagreb, 1991., str. 40-41.

39 Miodrag Al. PURKOVIĆ, Avinjonske pape i srpske zemlje, Požarevac, 1934., str. 4-5, 29-30.

${ }^{40}$ Miroslav M. POPOVIĆ, »Stefan Dragutin i rimokatolička crkva«, Baština, br. 41, Priština, Leposavić, 2016. str. 89.
} 
pridonositi jurisdikcijska nadmetanja barske i dubrovačke (nad)biskupije, koja traju sve do polovice 13. vijeka, kao i usredotočenost primorskih gradova, koji su bili središtima katolicizma na vlastite probitke. Njima je uostalom srpska vlast radi vlastitih interesa omogućila zadržavanje i daljnje širenje autonomnog statusa kao i ostanak u katoličanstvu. Tako se ono, unatoč prevjeravanjima, održalo na znatnom dijelu današnjeg Crnogorskog primorja, odnosno u Boki kotorskoj, Budvi, okolici Bara i Ulcinja. ${ }^{41}$

Uočljivo je da je pravoslavizaciji bio izložen slavenski katolički živalj. Stoga bi se moglo ustvrditi da je taj proces olakšavalo ćirilometodsko nasljeđe ovdašnjih katolika. Vjerojatno je sam proces otpočeo blago, time što je crkvena vlast nad katolicima prenesena s katoličkih biskupija na pravoslavne episkopije. U okolnostima učestalih iskaza vjernosti srpskih vladara Rimu takav transfer nije niti morao izgledati kao istupanje iz katolicizma. No, riječ je bila upravo o tome. Poslije toga prvog koraka postupno se otklanjalo katoličke i unosilo pravoslavne sadržaje. Nasuprot tomu, Albancima barske nadbiskupije, koliko god bili u podložnom položaju prema srpskoj vlasti i pravoslavlju, omogućeno je da ostanu u katoličkoj vjeri. Pa tako i u Gornjem Pilotu lociranom u sjevernim dijelovima Albanije uz granicu prema Kosovu. ${ }^{42}$ Istodobno, lociranost katolicizma na toj geografskoj točki dopušta pretpostavku da se zapadno od Gornjeg Pilota granica između katolicizma i pravoslavlja protezala približno rijekom Tarom. Tu liniju bi potvrđivali i podatci iz Ljetopisa popa Dukljanina po kojima se granica između primorskih oblasti (»Tetrarhija«) i Srbije približno nalazila na Tari. ${ }^{43}$

Da se proces pravoslavizacije u najvećoj mjeri odvio vrlo skoro po osnivanju Žičke arhiepiskopije mogla bi svjedočiti i sljedeća dva primjera. Srpski kralj Milutin predao je 1306./1307. kotorskoj komuni Grbalj, tj. kraj od nekih $100 \mathrm{~km}^{2}$ smješten između Boke kotorske i Budve. ${ }^{44} \mathrm{~S}$ obzirom na to da se kotorska komuna i sama nalazila pod srpskom vlašću, nije mogla provoditi rekatolicizaciju grbaljskog stanovništva. No jednako tako, nakon što je prepušten katoličkom Kotoru teško da se unutar Grblja mogao nastaviti proces pravoslavizacije. I to unatoč tomu što je se nalazio pored jednog od sjedišta zetske episkopije lociranog na Prevlaci kod Tivta. Također, ne može se očekivati da bi kotorska i srpska vlast prihvaćale nekakvo samovoljno znatnije transferiranje dijelova grbaljskog stanovništva iz jedne vjere u drugu. Iz toga bi se dalo zaključiti da se u stanje vjerskih odnosa kakvo je zatečeno 1306./1307. nije znatnije interveniralo ni s katoličke ni s pravoslavne strane. Jako je od tada Grbalj prošao kroz različite političke faze te bio zahvaćen raseljavanjima i useljavanjima, činjenica je da je riječ o pravoslavnom kraju. ${ }^{45} \mathrm{Ne}$ može-

${ }^{41}$ Saša MRDULJAŠ, »Etnički sastav naselja Boke kotorske prema popisu stanovništva iz 1900. godine«, Migracijske i etničke teme, god. 35, br. 3, Zagreb, 2019., str. 258-264.

42 Marica MALOVIĆ-ĐUKIĆ, »Pilot u srednjem veku«, Stanovništvo slovenskog porijekla u Albaniji. Zbornik radova sa međunarodnog naučnog skupa održanog na Cetinju 21-23. juna 1990. godine, Jovan P. BOJOVIĆ (ur.), Titograd (Podgorica), 1991., dostupno online, URL: http://www.rastko.rs/ (zadnje posjećeno 15. lipnja 2020.).

43 Ljetopis popa Dukljanina, str. 123.

${ }^{44}$ Miljan M. GOGIĆ, Političko i društveno uređenje Kotora u drugoj polovini XII i XIII vijeku, doktorska disertacija obranjena na Filozofskom fakultetu Univerziteta u Beogradu, Beograd, 2018., str. 67.

${ }^{45}$ Miloš MILOŠEVIĆ, »Grbaljske bune XV. stoljeća«, Radovi, god. 10, br. 1, Zagreb, 1977., str. 275, 299; Mithad KOZLIČIĆ - Ante BRALIĆ, Stanovništvo Kraljevine Dalmacije prema službenim izračunima i popisima 1828. - 1857. godine, Zadar, 2012. 
mo pretpostaviti da je pod vlast Kotora mogao doći s bitno drukčijom vjerskom slikom. ${ }^{46}$ Tad bi se u Grblju, smještenom između dvaju katoličkih središta, tj. Kotora i Budve, bar u nekoj minimalnoj formi održao katolicizam. Dakle, sukladno grbaljskom slučaju moglo bi se ustvrditi da je pravoslavizacija svoj najsnažniji zamah imala upravo u 13. vijeku.

Dva desetljeća nakon što su Kotorani stekli Grbalj, Dubrovčani su 1326. godine zauzeli Ston s Pelješcem. Taj posjed im je poslije potvrdio i srpski kralj Dušan uz zahtjev da se u tim krajevima omogući opstojnost pravoslavlja. ${ }^{47}$ Izgledno je da se tada pod Dubrovčanima našao i pravoslavizirani živalj, tim više što je u Stonu na mjestu nekadašnje katoličke biskupije jedno vrijeme bilo sjedište humske episkopije. No taj je dio Zahumlja kao granični kraj bio izložen hrvatsko-ugarskim utjecajima. Vjerojatno su oni bili jednim od razloga što je humski episkop polovicom 13. vijeka premjestio svoje sjedište kod današnjeg Bijelog Polja. Stoga u zapadnijim krajevima Zahumlja pravoslavizacija zasigurno nije bila onako temeljita kao u drugim dijelovima zahumsko-dukljanskog prostora. No, i u ovom slučaju prevjeravanje se moralo odviti tijekom 13. stoljeća jer srpska država gubi te krajeve već koncem istog vijeka. Moguće da je bilo najintenzivnije upravo od polovice 13. stoljeća, u vremenu nakon što je protjeran trebinjski biskup. ${ }^{48}$ U svakom slučaju, po izvještaju stonsko-korčulanskog biskupa Marina papi Klementu VI. (1342. - 1352.), odnosno iz izvještaja njegova nasljednika Ivana papi Grguru XI. (1370. - 1378.) rekatolicizacija je uslijedila vrlo brzo po dubrovačkom stjecanju Stona i Pelješca. ${ }^{49}$

Rekatolicizaciju započetu u stonsko-pelješkom kraju Dubrovačka Republika provodit će i na svojim jugoistočnim posjedima stečenim početkom 15. stoljeća. Rezultati pravoslavizacije u zapadnijim dijelovima nekadašnjeg Zahumlja, u onoj mjeri u kojoj ih je moglo biti u tom rubnom kraju, poništeni su rekatolicizacijom koja se odvija pod hrvatsko-ugarskim utjecajima te djelatnošću bosanskih franjevaca. ${ }^{50}$ Po određenim podatcima katolicizam je ostao prisutan i među pojedinim crnogorskim plemenima (Bjelopavlići, Piperi, Bratonožići, Kuči) sve do prve polovice 17. vijeka. ${ }^{51}$ No pitanje je da li se u tim slučajevima održao u kontinuitetu, dakle usprkos pravoslavizaciji ili je do njegove pojave došlo npr. posredstvom doseljavanja i slavizacije življa iz susjednih albanskih oblasti. Ukoliko se održao u kontinuitetu, moguće da je razlog tomu što su mogući ostatci izoliranih romansko-stočarskih grupacija, posebno onih u blizini Albanaca, bili manje podložni distanciranju od rimske forme kršćanstva i od romanskih katoličkih centara u Primorju. Na koncu, može se pretpostaviti da se u vrijeme srpske vlasti dio slavenskog življa nekadašnje Duklje koji je bio lociran u blizini Albanaca dodatno integrirao s njima, uspijevajući očuvati katoličku

${ }^{46}$ Lenka BLEHOVA ČELEBIĆ, Hrišćanstvo u Boki, str. 367-372.

${ }^{47}$ Mladen ANČIĆ, Na rubu zapada: tri stoljeća srednjovjekovne Bosne, Zagreb, 2001., str. 157-58.

${ }^{48}$ Ivica PULJIĆ, »Sedam stoljeća otoka Mrkana u naslovu trebinjskih biskupa«, Hercegovina, god. 26, br. 1, Mostar, 2015., str. 91-92.

${ }^{49}$ Milenko KREŠIĆ, »Vjerske prilike u Humskoj zemlji (Stonu i Râtu) u srednjem vijeku«, Hercegovina, br. 2, Mostar, 2016., str. 88-89.

${ }^{50}$ Mladen ANČIĆ, Na rubu zapada, str. 167, 172-73.

${ }^{51}$ Lenka BLEHOVA ČELEBIĆ, Hrišćanstvo u Boki, str. 23; Vladimir ĆOROVIĆ, Istorija Srba, str. 437; Krunoslav DRAGANOVIĆ, Masovni prijelazi katolika na pravoslavlje hrvatskog govornog područja u vrijeme vladavine Turaka, Mostar, 1991., str. 28-37. 
vjeru, ali ne i svoj jezik. O tome bi mogli svjedočiti uočljivi slavenski kulturni elementi kod znatnog dijela tamošnjih Albanaca. ${ }^{52}$

Za vladavine kralja, odnosno cara Dušana (1331. - 1355.) dolazi do nagle i prenapregnute ekspanzije Srbije do Soluna i Peloponeza. Nakon njegove smrti uslijedit će rastrojstvo države na niz cjelina pod oblasnim vladarima i to u okolnostima sve snažnije izloženosti osmanskim prodorima. U tim prilikama nekadašnje istočno Zahumlje i Travunija, zajedno s najzapadnijim dijelovima Raške (današnje Rudo, Čajniče, Priboj, Prijepolje, Pljevlja) dolaze pod bosanske vladare. Kako su se oni proglasili i kraljevima Srbije te iskazivali daljnje pretenzije prema toj zemlji, nije bilo očekivanim da u novostečenim oblastima ugrožavaju pravoslavlje. Štoviše, lokalni bosanski velikaš Stjepan Vukčić Kosača uzima 1448/1449. titulu hercega od sv. Save. ${ }^{53}$ Po njoj će cijeli teritorij pod njegovom vlašću, koji je uključivao i krajeve zapadno od Neretve, postati prepoznatljiv pod imenom Hercegovine.

Nekadašnji krajevi Duklje, sada već Zete, dospjeli su po rastrojstvu srpske države pod dinastiju Balšića (1360. - 1421.). S obzirom na političke prilike, tj. da su društveno-ekonomski najznačajniji prostori pod njihovom vlašću bili u pretežito katoličkim, primorskim i sjevernoalbanskim krajevima, Balšići početkom 1369. godine s pravoslavlja prelaze na katolicizam. ${ }^{54}$ Takav razvoj, popraćen njihovim sve samostalnijim statusom i osloncem na barsku metropoliju, mogao je sugerirati da dolazi ne samo do obnove državnosti nego i do zapadne orijentacije dukljanskog, tj. zetskog prostora. No do toga nije došlo. Đurađ II. Balšić (1385. - 1403.) pred osmanskom je opasnošću 1396. godine prepustio sjevernoalbanske krajeve Mletačkoj Republici. Njegov sin i nasljednik Balša III. (1403. - 1421.), ne mireći se takvom odlukom oca, ulazi u sukob s Venecijom oslanjajući se na Srpsku Despotovinu i Osmanlije. Pored toga, okreće se pravoslavlju te u konačnici prepušta Zetu Srbiji. Iduća zetska dinastija, odnosno Crnojevići, u prilici je neposredno prije teritorijalnog reduciranja Despotovine (1455.) te njezina konačnog pada (1459.) osamostaliti dio zetskih, ovaj put gotovo isključivo pravoslavnih prostora. Na njima su u razdoblju 1452. - 1479. vladali kao mletački saveznici, a od 1481. do 1496., tj. do potpadanja pod neposrednu vlast sultanata, kao osmanski vazali..$^{55}$

Za razliku od prvih Balšića, Crnojevići nisu imali razloga kalkulirati s katolicizmom. Štoviše, čvrsto su se oslanjali na pravoslavlje te u svom podlovćenskom uporištu u crnogorskom dijelu Zete podižu 1485. godine cetinjski manastir, koji postaje središtem mitropolije. Time su stvorene pretpostavke da podlovćenska Crna Gora u narednom dugom razdoblju obilježenom protuosmanskim oslobodilačkim naporima postane novim žarištem državnosti unutar teritorija nekadašnje Duklje. Riječ je bila o kontinuitetu državotvornih napora stanovništva jednog te istog prostora, ali ne i o kontinuitetu prijašnjih državotvornih tradicija, premda u novoj pravoslavnoj formi. »Sjećanje« na Duklju i kraljevstvo

\footnotetext{
${ }^{52}$ Mitar PEŠIKAN, »Svjedočanstva starih popisa o stanovništvu sjevernoalbanskog i susjednog jugoslovenskog područja krajem srednjeg vijeka«, Stanovništvo slovenskog porijekla u Albaniji. Zbornik radova ..., dostupno online, URL: http://www.rastko.rs/ (zadnje posjećeno 15. lipnja 2020).

${ }^{53}$ Marijan PREMOVIĆ, »Herceg Stjepan Vukčić Kosača i Polimlje«, Hercegovina, br. 3, Mostar, 2017., str. $110-111$.

${ }^{54}$ S. ĆIRKOVIĆ, »Doba Balšića« (»Balšići protiv Kotora«), Istorija Crne Gore, knjiga II: tom II, str. 25.

${ }_{55}$ Ivan BOŽIĆ, »Doba Balšića«, »Zeta u Despotovini«, »Vladavina Crnojevića«, Istorija Crne Gore, knjiga II: tom II, str. 56-57, 62-63, 86, 129-130, 150, 226, 317, 324, 346.
} 
Vojislavljevića sve do suvremenog doba nije imalo značaja u procesu crnogorske državne i etničke konstitucije. ${ }^{56}$

Do propasti države Nemanjića pravoslavlje je postalo prevladavajućom i čvrsto ukorijenjenom vjerom na glavnini nekadašnjeg zahumsko-dukljankog prostora, približno do linije koja bi na zapadu bila obilježena potezom Velež - Stolac - Popovo Polje - Konavle. ${ }^{57} \mathrm{U}$ današnjem Crnogorskom primorju ono se ispreplitalo s katolicizmom, a moguće i u pojedenim dijelovima slavenskog zaleđa. Ponajprije onim koji su se nalazili u blizini katoličke sjeverne Albanije. Takvo se stanje održalo pod bosanskom vlašću i pod vlašću Balšića te Crnojevića, odnosno do konačnog osmanskog zauzimanja Srbije, Bosne, Hercegovine i Crne Gore tijekom druge polovice 15 . stoljeća.

\section{Značenje pravoslavizacije zahumsko-dukljanskog prostora}

Pravoslavizacija glavnine zahumsko-dukljanskog življa imala je niz dalekosežnih posljedica na ovdašnje prilike i suodnose. Prva je bila u tome što je uzrokovala oštro podvajanje nekoć vjerski i kulturno jedinstvenog slavenskog življa između Neretve i Bojane. Sada je tek petina tog pojasa bila katolička, dok je veći dio bio pravoslavan. U tim uvjetima više se nije mogla obnoviti prijašnja razvojna linija, takva koja bi bila prihvatljivom ukupnosti stanovništva bilo na razini pojedinačnih povijesnih formacija, tj. Zahumlja, Travunije, Duklje ili pak na razini njihova međusobnog objedinjavanja kakvo se nekoć zbilo dukljanskom inicijativom. Pod srpskom je vlašću katoličko-pravoslavna crta razdiobe dislocirana s rijeke Tare sve do zapadnih i priobalnih krajeva nekadašnjeg zahumsko-dukljanskog prostora. Time je postavljena osnova različitom političkom, a posljedično tomu i etničkom oblikovanju njegove katoličke i pravoslavne populacije.

U vremenu za koje je temeljno kolektivno-identifikacijsko te političko-mobilizatorsko značenje imala religija, za katolike nekadašnjeg zahumsko-dukljanskog prostora presudno je bilo sačuvati vjerski identitet i to ponajprije pod katoličkom vlašću. U zapadnim dijelovima Zahumlja, odnosno istočne Hercegovine, katolički se živalj lako »preusmjerio« na kompaktne slavensko-katoličke krajeve u Hrvatskoj i Bosni. U priobalju nekadašnjeg Zahumlja i Travunije postaje dijelom katoličke Dubrovačke Republike, a time i nositeljem, državnom samobitnošću produciranog dubrovačkog (etno)identiteta. ${ }^{58} \mathrm{Na}$ današnjem Crnogorskom primorju vrlo brzo po rastrojstvu srpske države katolici se vežu uz Mletačku Republiku. Naknadno, u uvjetima stoljetne osmanske dominacije katolike nekadašnjeg zahumsko-dukljanskog prostora čvrsto je s ostalim katolicima njihova jezika povezivao protuosmanski naboj i aktivitet, pridonoseći njihovu zajedničkom srastanju u posebnu kulturnu cjelinu. Uvjeti kakvi

\footnotetext{
${ }^{56}$ Adnan PREKIĆ, »Crnogorska istoriografija i nacionalizam«, Ogledi o historiografiji i nacionalizmu u Jugoistočnoj Evropi: zbornik radova, Amir DURANOVIĆ (ur.), Sarajevo, 2019., str. 52-57, 63-64.

${ }^{57}$ Mladen ANČIĆ, »Kasnosrednjovjekovni Stolac«, Povijesni prilozi, god. 24, br. 29, Zagreb, 2005., str. 44-46, 54-57; Dijana KORAĆ, »Franjevci i njihovi samostani u Humu«, Croatica christiana periodica, god. 31, br. 60, Zagreb, 2007., str. 25-29. Domagoj VIDOVIĆ, »Pregled toponimije jugozapadnoga dijela Popova«, Folia onomastica Croatica, br. 19, Zagreb, 2010., str. 285-286.

58 »Politička zajednica grada-države za sebe je zahtijevala apsolutni primat kao identifikacijski okvir i objekt lojalnosti...« Lovro KUNČEVIĆ, »Etnički i politički identitet predmodernog Dubrovnika od 14. do 17. stoljeća«, Anali, br. 55/1, Zagreb, 2017., str. 72, 79, 81.
} 
su bili tijekom 19. stoljeća, na početku kojeg Dubrovnik gubi državnost, omogućili su da ta cjelina preraste u posebnu nacionalnu formaciju prepoznatljivu i po svom hrvatskom imenu. ${ }^{59}$ S druge strane, prevjereni dio zahumsko-dukljanskog življa nije posredstvom pravoslavlja samo stekao društvenu konekciju s istojezičnim pravoslavcima proširene Srbije. U sklopu srpskog pravoslavlja razvijan je i autentičan vjersko-državotvorni kult. Mada je njegova primarna svrha bila u snažnjenju pozicija dinastije Nemanjića, čemu je imalo poslužiti i kanoniziranje niza njezinih vladara, nužno je afirmirao srpsku državu te u širokim vjerničkim masama stvarao određenu svijest o njoj. ${ }^{60} \mathrm{Na}$ taj su način postavljani temelji protonacionalnog srpstva. Dakle srpstva koje uključuje donekle oblikovanu spoznaju o sebi, no koje sukladno uvjetima još dugo neće imati političko-mobilizatorsku ulogu. ${ }^{61} \mathrm{U}$ okolnostima nestanka srpske države i stoljetne osmanske vlasti činjenica što je unutar religijskog sustava bilo očuvano »sjećanje« na dvadesetak kanoniziranih (kasno)srednjovjekovnih srpskih vladara, a time i na državu, imala je daleko veći utjecaj nego da je ono prepušteno narodnom pamćenju. ${ }^{62}$ Međutim, kao što je istaknuto, taj segment srpskog pravoslavlja imao je limitiran doseg. U onim pak slučajevima gdje je uslijedila islamizacija, (grko)katolicizacija, zatim tamo gdje su domaće pravoslavno svećenstvo zamijenili grčki fanarioti, gdje je bio snažan utjecaj drugih pravoslavnih država i tradicija, poput Bugarske ili Rusije (kod srpskih iseljenika), gdje se na srpskoj protonacionalnoj podlozi stvorili uvjeti za samobitan razvoj, kako je bilo u Crnoj Gori, srpski je vjersko-državotvorni kult po naravi stvari gubio svoj značaj u potpunosti ili velikim dijelom.

Također, za trajanja osmanske dominacije, tijekom koje je uspostavljen određeni módus vivëndi između pravoslavlja i vladajućeg islama glavna preokupacija pravoslavnog življa najčešće je bila usmjerena na stjecanje i očuvanje što povoljnijeg socijalnog statusa. U tom smislu treba gledati na širenje i ukorjenjivanje vlaškog imena kako kod dijela ovdašnjih pravoslavaca tako i kod dijela katolika. Jer biti Vlahom prvotno je, u vremenu osmanskih prodora prema zapadu, značilo biti u službi sultanata, temeljno vojnoj te samim tim imati niz privilegija unutar osmanskog društvenog sistema. U ovom slučaju ne treba zavarati geneza vlaškog imena, izvorno vezana uz romanske starosjedioce Balkana. Pod Osmanlijama se ono u hrvatskim, bosanskim, srpskim i crnogorskim krajevima u pravilu veže uz slavenojezične mase. ${ }^{63}$ Najbolji trag tog vezivanja je dalmatinsko zaleđe, koje je iz priobalne perspektive do danas ostalo »Vlaškom «. Pritom je važno istaknuti da su Osmanlije u Dinaridima zatekle stanovništvo koje je bilo u vlaškom, uz stočarstvo vezanom statusu te da je ono bilo jezgrom osmanskog vlaškog sloja. No, takvog je stanovništva do osmanskih osvajanja bilo relativno malo na tlu Hrvatske, Bosne, Srbije te na nekadašnjem zahumskodukljanskom prostoru. ${ }^{64}$ Pod Osmanlijama se zatečena vlaška grupacija, sukladno vojnim

\footnotetext{
59 Nikša STANIČIĆ, Hrvatska nacija i nacionalizam u 19. i 20. stoljeću, Zagreb, 2002., str. 107-124.

${ }^{60}$ Branislav ĐURĐEV, Uloga Crkve u starijoj istoriji srpskog naroda, Sarajevo, 1964., str. 75-79.

${ }^{61}$ Lásló HADROVICS, Srpski narod i njegova crkva pod turskom vlašću, Zagreb, 2000., str. 12; Eric J. HOBSBAWM, Nacije i nacionalizam: program, mit, stvarnost, Zagreb, 1993., str. 53.

${ }^{62}$ Dušan Lj. KAŠIĆ, Pogled u prošlost srpske crkve, Beograd, 1984., str. 72-73.

${ }^{63}$ Ferdo ŠIŚIĆ, Pregled povijesti hrvatskog naroda od najstarijih dana do godine 1873., Zagreb, 1916., str. 235-236; Milan VASIĆ, Martolosi u jugoslovenskim zemljama pod turskom vladavinom, Sarajevo, 1967. str. 32-44, 146-147.

${ }^{64}$ Milomir MAKSIMOVIĆ, »Mileševski Vlasi (XIII-XV vek)«, Crkvene studije, god. 16, br. 16/2, Niš, 2019. str. 214, 222, 229.
} 
i kolonizacijskim potrebama Carstva, izrazito omasovljava inkorporacijom nekadašnjeg zavisnog zemljoradničkog stanovništva. ${ }^{65}$

Pravoslavizacija nekadašnjeg zahumsko-dukljanskog prostora odvijala se paralelno s oblikovanjem srpskog protonacionalnog sustava. Stoga je prevjereni živalj otpočetka bio uključen u taj sustav te je ujedno bio njegovim nositeljem. No političkim i državnim razvitkom podlovćenske Crne Gore, koji se odvija u sukobima s Osmanlijama, na dijelu nekadašnjeg zahumsko-dukljanskog prostora oblikuje se nova identitetna stvarnost. Podlovćenska Crna Gora, s okosnicom u cetinjskom manastiru, tj. metropoliji, steći će ulogu svojevrsnog bedema pravoslavlja te će kao takva biti privlačna okolnom pravoslavnom življu, što će olakšati njezino širenje približno do današnjih okvira. Pritom će onodobno srpstvo zadržavati svoje pozicije. ${ }^{66}$ No dobit će konkurenciju u protonacionalnom crnogorstvu stvaranom kroz stoljetni samobitni razvitak. Taj dualitet, koji postepeno stječe sve oštriji (među)nacionalni značaj, do danas nije razriješen ${ }^{67}$ Pritom pojava crnogorstva jasno svjedoči da su uz srpsku protonacionalnu svijest trebali postojati i drugi uvjeti kako bi došlo do srpske narodnosne konstitucije. Oni su npr. postojali u istočnoj Hercegovini (Zahumlje i dio Travunije), koja je do nacionalno-formativnih procesa ostala pod osmansko-islamskom, a zatim austrougarskom katoličkom vlašću, što je njezin pravoslavni živalj pravocrtno usmjerilo prema suvremenom srpstvu.

Pod osmansku su vlast bez izrazitijeg otpora potpale Srbija, Bosna, južni dio srednje Dalmacije, Hercegovina, Crna Gora te se u njima uglavnom održao domicilni živalj. No, približno na potezu Klis - Sinj - Jajce - Doboj - Janja (donje Podrinje) i dalje prema Dunavu formirana je po padu Bosne 1463. godine prilično stabilna ugarsko-hrvatsko-bosanska linija obrane. ${ }^{68}$ Kroz narednih 130 godina nju će Osmanlije pomjeriti nekih sto i pedeset kilometara zapadnije, no krajevi koje su zauzeli bili su opustošeni. Te osvojene, ali depopulizirane teritorije Osmanlije uglavnom naseljavaju srpsko-pravoslavnim življem novoštokavsko-ijekavskog govora. ${ }^{69}$ Taj govor svoje sigurno izvorište ima upravo na tlu nekadašnjeg Zahumlja i Travunije, a moguće i u Gornjem Podrinju. ${ }^{70}$

Također, nakon pustošenja Srbije u habsburško-osmanskim ratovima s kraja 17. i tijekom 18. stoljeća pravoslavni živalj nekadašnjeg zahumsko-dukljanskog prostora, kako novo-

${ }^{65}$ Marko PIJOVIĆ, Vlasi u dubrovačkim spomenicima do 14. stoljeća, doktorska disertacija obranjena na $\mathrm{Hr}-$ vatskim studijima Sveučilište u Zagrebu, Zagreb, 2018., str.142-144, 321-335.

${ }^{66}$ Crnogorski identitet: Zbornik dokumenata o jeziku, narodu i vjeri, Budimir DUBAK (ur.), Podgorica, 2011., str. 7-17, 23-37.

${ }^{67}$ Po popisu stanovništva iz 2011. godine u Crnoj Gori je bilo 620029 stanovnika među kojima 278865 ili 44,98\% Crnogoraca te 178.110 ili 28,73\% Srba (Popis stanovništva, domaćinstava i stanova u Crnoj Gori 2011. godine. Stanovništvo Crne Gore prema polu, tipu naselja, nacionalnoj, odnosno etničkoj pripadnosti, vjeroispovijesti i maternjem jeziku po opštinama u Crnoj Gori, Saopštenje br. 83, Podgorica, 2011., str. 6, 8.

${ }^{68}$ Ive MAŽURAN, Hrvati i Osmansko Carstvo, Zagreb, 1998., str. 34-39.

69 »Izvršena je svojevrsna, u planetarnim razmjerama specifična, rekolonizacija prostranih krajeva čije je prethodno stanovništvo bilo drastično prorijeđeno ili potpuno istrijebljeno. Ovaj talas pada u razdoblje XV i XVI vijeka, kada se formira tzv. sjeverozapadni poddijalekat hercegovačko-krajiškog dijalekta (novoštokavskoijekavskog, S. M.), u kojem izostaju kasniji inovativni impulsi njegove kolijevke. Nekoliko stoljeća kasnije, u XVIII i početkom XIX vijeka, ekonomski motivisane migracije, praktično isti rasadnik, nasuće nosiocima hercegovačkoga govora jugoistočnu (i istočnu) Bosnu i zapadnu Srbiju.« Slobodan REMETIĆ, »Bosanski srpski govori u svjetlu dijalekatske interferencije (lingvistički i sociolingvistički aspekt)«, Zbornik, god. 52, br. 1, Novi Sad, 2009., str. 151.

${ }^{70}$ Pavle IVIĆ, Srpski narod i njegov jezik, Beograd, 1986., str. 42-43, 57-58, 64, 74. 
štokavsko-ijekavskog tako i arhaičnijeg zetskog ijekavskog govora, koji svoje izvorište ima na nekadašnjem tlu Duklje, otpočinje masovno naseljavati jugozapadnu Srbiju. ${ }^{71} \mathrm{U}$ razdoblju seoba prema Hrvatskoj, Bosni, a poslije i Srbiji, dio starinačkog ili iz drugih krajeva doseljenog življa zasigurno je jezično asimiliran u novoštokavsko-ijekavski i zetski govor. No ipak bi se moglo ustvrditi da s relativno malog zahumsko-dukljanskog prostora, od nekoć pravoslaviziranog življa, pored Crnogoraca, potječe i najveći dio od približno trećine današnjih Srba koji se tradicionalno služe ijekavskim govorima. Dakle, Srbi porijeklom iz Hrvatske (izuzev onih iz dijela Podunavlja), BiH i jugozapadne Srbije (vidjeti kartu br. 1).

S aspekta ovdašnjeg katolicizma, pravoslavizacija glavnine zahumsko-dukljanskog življa predstavljala je velik gubitak. U brojčanom smislu veći od onog koji je uzrokovan islamizacijom. Stoga se na pravoslavizaciju tako može gledati i s pozicija suvremenog hrvatstva, čijim su dijelom postali katolici nekadašnjeg zahumsko-dukljanskog prostora. Međutim, valja uzeti u obzir i naknadni razvoj, činjenicu stoljetnog sukoba katoličkih država s osmansko-islamskom Carstvom. Tijekom njegova trajanja Osmanlije su gotovo u potpunosti razgradile katoličku strukturu na zapadnobalkanskom tlu istodobno potičući masovnu islamizaciju ponajprije bosanskih te albanskih katolika. ${ }^{72}$ Primjerice, do osmanskih prodora na tlu današnje BiH bilo je gotovo četrdesetak samo franjevačkih samostana. Nakon Bečkog rata 1683. - 1699. preostala su svega tri (Fojnica, Kreševo, Kraljeva Sutjeska). ${ }^{73}$

O tome da su u Bosni masovno islamizirani upravo katolici svjedoči što se govorima koji su autohtoni u njoj, odnosno novoštokavsko-ikavskim (mlađim ikavskim) i šćakavskoijekavskim (istočnobosanskim) u pravilu služe Hrvati i Bošnjaci. ${ }^{74}$ Srbi su prihvatili te dijalekte ili češće njihove elemente samo tamo gdje su bili uočljivom manjinom prema navedenim dvama narodima. S tim da su u takvim slučajevima najčešće zadržali i određene značajke svog izvornog novoštokavsko-ijekavskog govora. ${ }^{75}$ Nadalje, sjevernoalbanski katolički krajevi masovno su islamizirani. No još u znatnijoj mjeri islamizirani su iseljenici s toga matičnog albanskog teritorija kolonizirani na Kosovu i u Makedoniji. Među onima na Kosovu katolicizam se održao tek sporadično, dok su makedonski Albanci u

71 Danilo BARJAKTAREVIĆ, »Novopazarsko-sjenički govori«, Srpski dijalektološki zbornik, knjiga 16, Beograd, 1966., str. 16, 21, 40-42; Pavle IVIĆ, Srpski narod ..., str. 66-67.

72 Do osmanske okupacije Bosne praktički je eliminirana samosvojna Crkva bosanska, a njezini vjernici, tj. »krstjani«, kako su sami sebe nazivali, djelovanjem franjevačkog reda gotovo su potpuno rekatolicizirani. U današnjoj istočnoj Hercegovini te dijelovima jugoistočne Bosne, koje su Osmanlije zauzeli do polovice 15. stoljeća, vjerojatno je dio »krstjana« prešao na pravoslavlje. Njihove neznatne ostatke registrirali su osmanski porezni popisi (defteri) sve do početka 17. stoljeća, kada im nestaje traga. Vidi: Srećko M. DŽAJA, Konfesionalnost $i$ nacionalnost Bosne i Hercegovine, Sarajevo, 1992., str. 25-27, 43; Srećko M. DŽAJA Dubravko LOVRENOVIĆ, »Srednjovjekovna Crkva bosanska«, Svjetlo riječi, Sarajevo, siječanj 2007., str. 14; Dubravko LOVRENOVIĆ, »Utjecaj Ugarske na odnos crkve i države u srednjovjekovnoj Bosni«, Sedam stoljeća bosanskih franjevaca 1291-1991., Marko KARAMATIĆ (ur.), Sarajevo, 1991., str. 85, 86-87, 92; Franjo ŠANJEK, Bosansko-humski krstjani u povijesnim vrelima, Zagreb, 2003., str. 28-30; Snježana VASILJ i sur., Katoličanstvo u Bosni i Hercegovini, Sarajevo, 1993., str. 56-58.

73 S. M. DŽAJA, Konfesionalnost i nacionalnost, str. 134-141.

${ }_{74}$ Dževad JAHIĆ, Jezik bosanskih Muslimana, Sarajevo, 1991., str. 9-14.

75 S. REMETIĆ, »Bosanski srpski govori«, str. 151-57, 174; Slobodan REMETIĆ, »O šćakavizmu kakanjskih i zeničkih Srba«, Južnoslovenski filolog, god. 56, br. 3-4, Beograd, 2000., str. 932, 939, 1047-48. 
potpunosti islamizirani. ${ }^{76}$ Pritom je uočljivo da je pravoslavni živalj u znatnijoj mjeri prelazio na islam upravo tamo gdje je obitavao pored Albanaca, $\mathrm{tj}$. $\mathrm{u}$ jugoistočnim dijelovima Crne Gore, istočnom Sandžaku, Kosovu i Makedoniji.

Sukladno rečenom, postavlja se pitanje da je zahumsko-dukljanski prostor dočekao Osmanlije kao katolički, bi li prošao kao susjedni masovno islamizirani bosanski i albanski krajevi? Bi li time došlo i do islamizacije dijelova Hercegovine i Dalmacije koji su pod Osmanlijama ostali katolički te odigrali ulogu hrvatskog narodnosnog rezervoara iz kojeg su naseljavani veliki dijelovi srednje i sjeverne Dalmacije, Like, Bosne, Slavonije itd. Bi li u tom slučaju iz zahumsko-dukljansko prostora prema opustošenim dijelovima Hrvatske i Bosne a poslije i Srbije, umjesto seoba pravoslavne populacije krenule masovne migracije muslimanskog i islamizaciji izloženog življa? Islamizirani živalj sasvim sigurno, za razliku od pravoslavaca, ne bi sudjelovao na katoličkoj mletačkoj i habsburškoj strani tijekom oslobodilačkih ratova s Osmanlijama. Stoga se pitamo je li možda prethodno provedenom pravoslavizacijom spriječena mogućnost naknadne islamizacije praktički kompletnog dinarskog pojasa? I kakva bi u tom slučaju bila politička pozicioniranost »ostataka ostataka« katolika jadransko-dinarske zone?

Dolaskom pod srpske vladare i pravoslavizacijom prekinut je dotadašnji državno-politički, vjerski etnički razvoj zahumsko-dukljanskog prostora. Naknadnim zbivanjima, obilježenim osmanskom prevlašću, islamizacijom dijela stanovništva, pojavom i etabliranjem Crne Gore, propašću Dubrovačke Republike itd. stvarani su daljnji uvjeti da se nekadašnje zahumskodukljansko stanovništvo u konačnici diferencira u četiri nacije: hrvatsku, bošnjačku, srpsku i crnogorsku. Riječ je o jedinom tlu na kojem su pripadnici svih četiriju naroda autohtoni i na kojem dijele onaj dio povijesti koji je prethodio njihovoj međusobnoj dezintegraciji. Stoga je razumljivo da je taj dio povijesti inkorporiran u okvire svake od četiriju nacionalno-identitetskih sfera. No, njezine interpretacije nerijetko se radikalno razlikuju. Manje stoga što razdoblje samosvojnog oblikovanja zahumsko-dukljanskog prostora i nije jednostavno dovesti u kontekst suvremenih nacionalnih (samo)percepcija. Presudno je što su te interpretacije najčešće determinirane različitošću povijesnih iskustva, državotvornih težnji, rigidnim doživljajima vlastitog i »tuđih« nacionaliteta. S obzirom na to, percepcije zahumsko-dukljanskog prostora i nadalje su u znatnoj mjeri opterećene pokušajima asimilacije onog »drugoga«, pa makar tek u vlastitoj doživljajnoj sferi. Sve s ciljem pojednostavljivanja njegove složenosti, a u korist vlastitog nacionalnog komoditeta. Nažalost, jer bi u drukčijim okolnostima, nakon svih razmimoilaženja iz prošlosti i njima unatoč, upravo zajednički segment povijesnosti zahumsko-dukljanskog prostora mogao pridonijeti smislenijoj i korisnijoj artikulaciji hrvatsko-bošnjačko-srpsko-crnogorskih odnosa.

\section{Zaključak}

Polovicom 11. stoljeća u zapadnim južnoslavenskim krajevima otpočinje važan integrativni proces predvođen inicijativom dukljanske kneževine. Državno objedinjavanje triju dotad samosvojnih entiteta, odnosno Zahumlja, Travunije i Duklje moglo je sugerirati da

${ }^{76}$ Shan ZEFI, Islamizacija Albanaca i fenomen ljarmanstva tijekom stoljeća (XV. - XX.), Zagreb, 2003., str. $62-87$. 
između Neretve i Bojane nastaje znatno etabliranija državna i etnička formacija. Tomu u prilog išla je činjenica da je riječ bila o državi kojoj je papinstvo priznalo status kraljevine, koja je imala vlastitu crkvenu organizaciju na čelu s barskom metropolijom, koja je iskazivala sposobnost širenja u bosansko i srpsko zaleđe. No, unutrašnji sukobi i vanjski pritisci doveli su polovicom 12. stoljeća do njezina slabljenja te krajem istog vijeka zahumskodukljanski prostor dolazi pod gotovo dvjestogodišnju vlast pravoslavne Srbije.

Pod srpskom dinastijom Nemanjića radikalno je izmijenjen razvojni smjer zahumskodukljanskog prostora. S ciljem jačanja dinastičke vlasti, u uvjetima sve oštrije polarizacije katoličko-pravoslavnih odnosa, glavnina je zahumsko-dukljanske populacije prevjerena iz katolicizma u pravoslavlje. Time nastaju dalekosežne posljedice. Podvojenost rečenog življa na manji katolički te brojniji pravoslavni segment postat će osnovom daljnje etničke diferencijacije. Ona će dodatno biti upotpunjena islamizacijom dijela stanovništva te oblikovanjem crnogorske države i etniciteta. U konačnici će ta ista populacija, čemu će pridonijeti i pad Dubrovačke Republike, postati dijelom četiriju nacija, tj. hrvatske, srpske, bošnjačke i crnogorske. Također, za trajanja osmanske prevlasti, zahumsko-dukljanski pravoslavni živalj postat će glavnim kolonizatorskim elementom opustošenih dijelova Hrvatske, Bosne i jugozapadne Srbije.

S aspekta katoličanstva, pa i samog nacionalnog hrvatstva, čijim su dijelom postali katolici nekadašnje države Vojislavljevića, pravoslavizacija glavnine zahumsko-dukljanskog prostora može izgledati kao veliki povijesni poraz. No, sukladno daljnjem razvoju, koji će biti obilježen rastvaranjem katoličkih struktura pod osmanskom vlašću i masovnom islamizacijom katolika, na pravoslavizaciju bi se moglo gledati i iz drugog kuta. Naime, da je zahumsko-dukljanski prostor došao pod Osmanlije kao katolički, da je kao takav, poput susjednih albanskih i bosanskih krajeva podlegao islamizaciji, iz njega bi se put opustošenih dijelova Hrvatske, Bosne i jugozapadne Srbije raselio muslimanski ili islamizaciji izloženi živalj, čime bi preostaci katolika u jadransko-dinarskom pojasu bili dovedeni u znatno nepovoljniji geopolitički položaj.

Razdoblje samosvojnog oblikovanja zahumsko-dukljanskog prostora, uključujući ono u kojem je bio definiran pripadnošću katolicizmu, svaka od četiriju nacija konstituiranih na tom prostoru mora na neki način uklopiti u vlastitu povijesnu percepciju. Bilo bi poželjno da se one zasnivaju na validnim osnovama i da su kao takve međusobno bliske. U postojećim prilikama, određenim dubokim nacionalno-političkim razmimoilaženjima, u pravilu nije tako. Stoga zahumsko-dukljanski prostor, iako predstavlja jednu od točaka s koje se ponajbolje može razjasniti bit identiteta suvremenog hrvatstva, bošnjaštva, srpstva i crnogorstva kao i njihov suodnos, do daljnjega ostaje točkom koja uvelike producira prijepore, začuđenost pojavom »onih drugih« te pokušaje njezina nadilaženja pomoću nacionalnoterapeutskih imaginacija. 


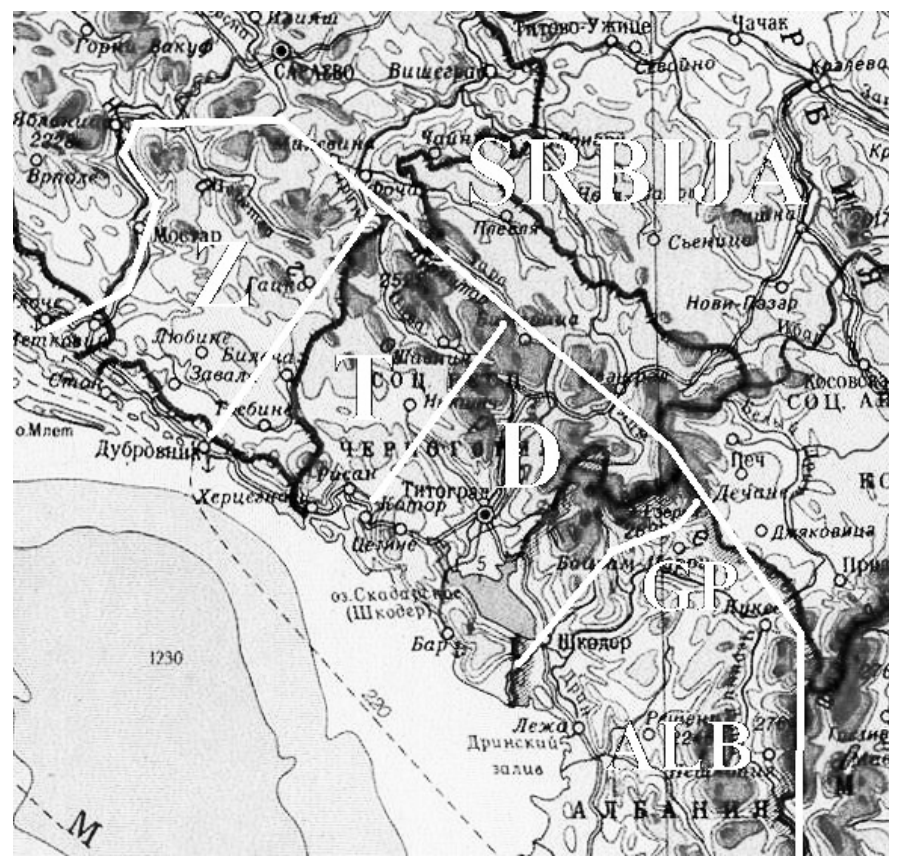

Karta br. 1.

Današnje države i položaj Zahumlja, Travunije i Duklje (9. - 12. stoljeće)

1. tamne linije - granice današnjih država (Hrvatska, Bosna i Hercegovina, Crna Gora, Albanija, Srbija, Kosovo); 2. bijele linije približne granice Zahumlja, Travunije, Duklje i albanskog etničkog prostora; 3. »Z«, »T«, »D« - Zahumlje, Travunija, Duklja; 4. »Srbija« - srpska državna jezgra; 5. »GP« - Gornji Pilot, tj. najsjevernija albanska etnička točka na kojoj se ujedno održao katolicizam unutar nemanjićke Srbije; 6. »ALB« - pretežito albanski etnički prostori. Oznake na karti ucrtao: dr. sc. Saša MRDULJAŠ. Predložak karte dostupan posredstvom: URL: https://dic.academic.ru/pictures/bse/jpg/0210964852. jpg (zadnje posjećeno 15. lipnja 2020).

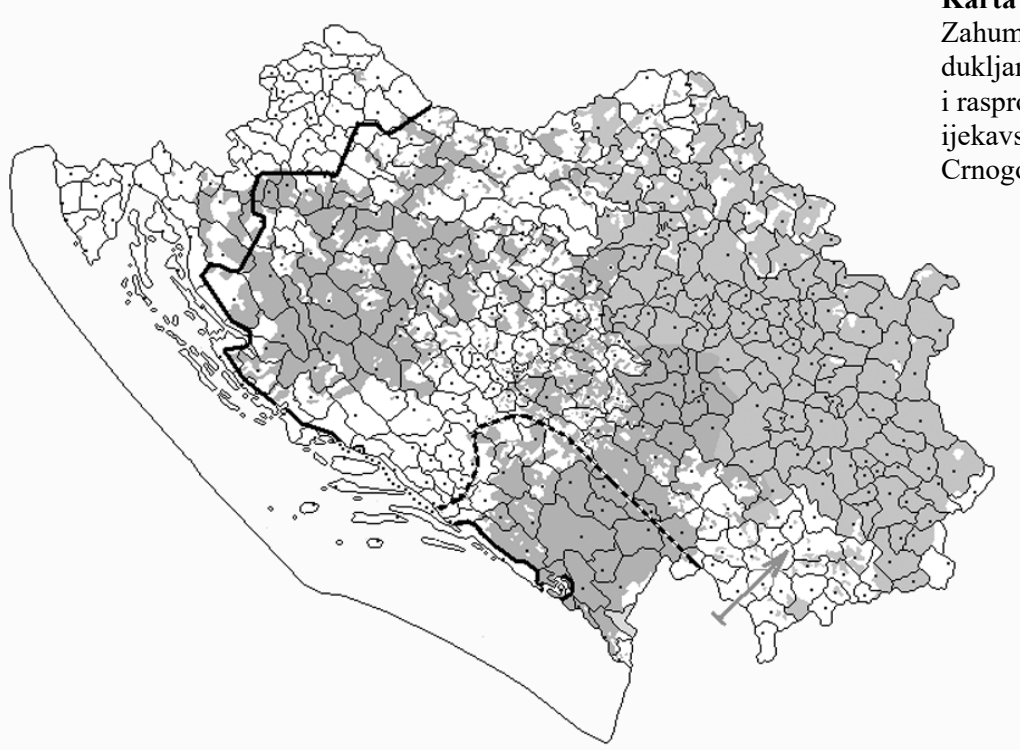

Karta br. 2.

Zahumsko-

dukljanski prostor i rasprostranjenost jekavskih Srba i Crnogoraca 
1. tanke linije - granice općina unutar Hrvatske, BiH, Srbije i Crne Gore (1981/91); 2. točke - općinska središta; 3. isprekidana linija - granice zahumsko-dukljanskog prostora; 4. puna linija - crta na kojoj su zaustavljeni osmanski prodori; 5. tamnosivo - Srbi ijekavskih govora i Crnogorci; 6. svijetlosivo - Srbi ekavskih govora; 7. strjelica - pravac albanske kolonizacije iz sjeverne Albanije prema Kosovu (Srbiji).

Kartu izradio dr. sc. Saša MRDULJAŠ prema podatcima: 1) granice općina prema: Stipe POJATINA (gl. ur.), Veliki geografski atlas Jugoslavije, Zagreb, 1987.; 2) etnički rasporedi za Srbiju i Crnu Goru odnose se na popis stanovništva iz 1981., a za Hrvatsku i BiH na popis iz 1991. te su urađeni prema podatcima kod: Jasna CRKVENČIĆ-BOJIĆ (ur.), Popis stanovništva Hrvatske 1991. - narodnosni sastav stanovništva Hrvatske po naseljima, Zagreb, 1992.; Jasna CRKVENČIĆ-BOJIĆ (ur.), Stanovništvo Bosne i Hercegovine - narodnosni sastav po naseljima, Zagreb, 1995.; Dušanka HADŽI-JOVANOVIĆ (ur.), The Serbian Questions in the Balkans, Belgrade, 1995., URL: http:/www.rastko.rs/ (zadnje posjećeno 15. lipnja 2020.); 3) raspored ijekavskih govora u Srbiji i na Kosovu: Marinko BOŽOVIĆ, »Glas jat (Ђ) u govorima srednjeg Ibra«, Baština, br. 12, Priština : Leposavić, 2001., str. 103, 113; Slavoljub Z. MARKOVIĆ, »Granice ijekavskih govora u zapadnoj Srbiji«, Srpski dijalektološki zbornik, knjiga 59, Beograd, 2012., str. 418-419, 439-440, 458-459.

\section{SUMMARY \\ IMPORTANCE OF RELIGIOUS CONVERSIONS OF THE POPULATION IN ZETA AND DOCLEA FROM CATHOLICISM TO ORTHODOXY $\left(13^{\text {th }}-14^{\text {th }} C E N T U R Y\right)$}

In respect of historical and political formation of ethnical and national communities, as well as regarding the differences between Croatians, Bosnians, Serbs and Montenegrins the religion played a paramount role. In this region the first important religion differentiation happened with division of Christianity to the Catholicism and the Orthodoxy. However, the initial borderline between Catholicism and Orthodoxy, the one from the time of Schism of 1054, did not last for a long time. Namely, the borderline was changed to the detriment of Catholicism after the former maritime duchies of Zachlumia, Travunija and Doclea, in the area between rivers Neretva and Bojana, became a part of Orthodox Serbian state at the end of the twelfth century. In order to religiously unify country, and consequently stabilize the political position of the ruling Serbian Nemanjic dynasty, the authorities ordered a massive religious conversion of the Catholic population in Zachlumia and Doclea to Orthodoxy. The conversion was probably the most intensive in the period between foundation of the autocephalous Serbian Church, i.e. Archbishopric of Žić and Peć, in 1219 and the end of the thirteenth century. Therefore, by the mid fourteenth century and ending of the Serbian rule this region of Zachlumia and Doclea became predominately Orthodox. In this article, beside the description of the political and religious circumstances that preceded and helped the conversion to Orthodoxy, author tried to emphasize far-reaching importance of this act to contemporary ethnic relations.

KEY WORDS: Zachlumia; Travunija; Doclea; Catholicism; Orthodoxy; religious conversions. 